\title{
EFFECT OF DIFFERENT PRE-TREATMENTS ON DRYING OF RAINBOW TROUT
}

\author{
Osman İSMAİL ${ }^{*}$ (D) Özlem GÖKÇE KOCABAY ${ }^{1,2}$ \\ ${ }^{l}$ Department of Chemical Engineering, Faculty of Chemical and Metallurgical Engineering, Yıldız Technical University, Davutpasa Campus, 34210 \\ Esenler, İstanbul, Turkey \\ ${ }^{2}$ T.R. Ministry of Culture and Tourism, Istanbul, Turkey
}

\begin{abstract}
Effects of different pre-treatments (citric acid, blanching and salt water dipping) and drying conditions on rainbow trout (Oncorhynchus mykiss) fillet samples at the cabinet laboratory type dryer were analyzed. Drying tests were carried out at 40, 50 and $60^{\circ} \mathrm{C}$. According to the obtained results the moisture content was considerably affected by the pre-treatment type and drying air temperature. When compared the drying times of rainbow trout fillet samples, it was observed that blanched $>$ citric acid $>$ salted $\geq$ control. The drying data for the moisture ratio versus time was fitted to 4 different thin-layer models. The best fit for the simulated drying models was specified by use of the highest determination of coefficient value $\left(\mathrm{R}^{2}\right)$, the lowest reduced chi-square $\left(\chi^{2}\right)$ value and the lowest root mean square error (RMSE). The Midilli et al. model was found to be the most appropriate model in explaining the drying properties of rainbow trout fillets.
\end{abstract}

Keywords: Rainbow trout, Hot air drying, Pre-treatment, Thin-layer models

\section{GÖKKUŞAĞI ALABALIĞI'NIN KURUTULMASI ÜZERİNE FARKLI ÖN- IŞLEMLERIN ETKİSI}

\section{ÖZET}

Gökkuşağ1 alabalığı (Oncorhynchus mykiss) fileto numuneleri üzerinde farklı ön-işlem (sitrik asit, haşlama ve tuzlu suya daldırma) ve kurutma koşullarının etkileri kabin laboratuvar tipi kurutucuda incelenmiştir. Kurutma deneyleri sırasıyla 40, 50 ve $60^{\circ} \mathrm{C}$ 'de gerçekleştirilmiştir. Elde edilen sonuçlara göre nem içeriği ön-işlem türü ve kurutma hava sıcaklığından önemli ölçüde etkilenmiştir. Gökkuşağı alabalığı fileto numunelerinin kurutma süreleri karşılaştırıldığında haşlama $>$ sitrik asit $>$ tuzlu suya daldırma $\geq$ doğal olduğu gözlenmiştir. Zamana karşı nem oranı için kurutma verisi 4 farklı ince-tabaka modeline uydurulmuştur. Simüle edilen kurutma modelleri için en iyi uyum en yüksek determinasyon katsayısı $\left(\mathrm{R}^{2}\right)$ değeri, en düşük indirgenmiş ki-kare $\left(\chi^{2}\right)$ değeri ve en düşük kök ortalama kare hatası (RMSE) kullanımıyla belirlenmiştir. Midilli ve diğerleri modeli Gökkuşağı alabalığı filetolarının kurutma özelliklerini açıklamada en uygun model olarak bulunmuştur.

Anahtar kelimeler: Gökkuşağı alabalığı, Sıcak hava kurutma, Ön-işlem, İnce-tabaka modelleri

\section{INTRODUCTION}

Increasing of world population day by day is required using more productive limited nutritional sources. Particularly not increasing of animal protein sources regularly in spite of increasing world population continually, increases gradually per capita animal protein deficit. In today's world it was understood that not only feeding of people but also balancedly feeding is an important subject [1]. In Turkey important development is observed in recent years in fisheries production and consumption area.

Either possessed extensive natural resources or improvements in technical, economical and social life are factors which affect development of sector. Fisheries has an important position in closing the deficit of country's population animal protein and in reaching sufficient and balanced nutrition level. Substantial part of fishery products which are coached and preying in Turkey are consumed as fresh. Another part is processed as animal feed in the fish meal and fat factories. This situation causes important loss in national economy. As well as fisheries is a valuable foodstuff rich in protein, because of having poor meat structure in respect of connective tissue it is a perishable foodstuff and in consequence of high $\mathrm{pH}$ and moisture content it deteriorates quicker

* Sorumlu yazar / Corresponding author, e-posta / e-mail: ismail@yildiz.edu.tr

Geliş / Recieved: 23.05.2019 Kabul / Accepted: 23.09.2019 doi: 10.28948/ngumuh.569239 
according to other animal products [2]. Turkey has an important position in rainbow trout production. There are a large number of rainbow trout, including rainbow trout, which breeds naturally and breeds in hatchery. Drying of consumption surplus is important for long-term storage. Therefore, rainbow trout was used in this study.

Some conservation methods are used for rendering continuous consumption of fisheries by slowing down degradation process. One of the oldest known drying methods is open sun drying. Natural sun drying is practiced widely in most tropical and subtropical countries and also in Turkey. Drying is an evaporation process of foodstuff's containing water under controlled conditions. The most important purpose of this process is increasing of working life of products which has short working life. In other words it is the oldest fish hardling method which removes fish's water amount by drying and gets inappropriate level for reproduction and growing of bacteria. Reduction of food's moisture content to between 10 and $20 \%$ w.b. prevents bacteria, yeast, mold and enzyme damage [3]. Recently solar and mechanical dryers have been introduced to speed up the drying process considerably to give a product of acceptable quality and extended shelf life [4].

In the closed drying systems undesired changes taken place in the processes that committed high temperature short time or low temperature long time with regard to heat treatment can be minimised by optimisation of methods which applied in processes [5]. Most especially antioxidants' decomposition in the hot drying and open drying process is an important quality loss. These quality losses taken place can be eliminated by drying process at the low and high temperature [6].

In addition, improvement in dried foods quality can be achieved by applying various pre-treatments before drying process. Pre-drying treatments like blanching and dipping in salt solution could also be used to improve quality [7]. Blanching, soaking in solution inactivate the enzyme activities (quality reduction and deterioration reduced), and improve product acceptability [8], [9]. Studies show that pre-treatment can speed up drying rate, improve quality of dried product, prevent browning, and help keep volatile compounds [7], [10].

In this study, rainbow trout fish fillets were dried. The objective of this study was to study the effect of different pre-drying (citric acid, blanching and salt water dipping) treatments and three different drying temperatures $\left(40,50\right.$ and $\left.60^{\circ} \mathrm{C}\right)$ on the drying time. Also Henderson and Pabis, Page, Logarithmic and Midilli et al., models were fitted to the experimental data for obtaining the best model for the the drying kinetics of the fish fillets.

\section{MATERIALS AND METHODS}

\subsection{Material}

Rainbow trout (Oncorhynchus mykiss) was obtained from Carrefour SA in Istanbul, Turkey. The selected samples were cleaned with tap water. Surface water was removed by blotting with an absorbent paper. The samples were cut into sheets (fillet) with an average length of $10 \pm 0.5 \mathrm{~cm}$, average width of $5.0 \pm 0.5 \mathrm{~cm}$ and thickness of $1.2 \pm 0.2 \mathrm{~cm}$. Dry matter and moisture contents of the fresh samples were determined prior to drying process. To determine the initial moisture content, four $10 \mathrm{~g}$ samples were dried in an oven (Memmert UM-400, Germany) at $105^{\circ} \mathrm{C}$ for $24 \mathrm{~h} \mathrm{[11].} \mathrm{The} \mathrm{average} \mathrm{initial} \mathrm{moisture} \mathrm{content} \mathrm{of} \mathrm{rainbow} \mathrm{trout}$ was found as $71.95 \pm 0.02 \%$ w.b.

\subsection{Application of Treatments}

The samples were pretreated with different solutions for inactivation of enzymes. The pre-treatments selected for the present study are as follows:

Salting: Samples were immersed in solution of $10 \% \mathrm{NaCl}$ at room temperature for $3 \mathrm{~min}$

Blanching: Samples were immersed in hot water at $80^{\circ} \mathrm{C}$ for $1 \mathrm{~min}$ and then immediately placed under running cold water for at least 3 min to cool down to room temperature and finally drained

Citric acid: Dipping for $3 \mathrm{~min}$ in solution of $0.5 \%$ citric acid at room temperature

Control: Untreated samples

\subsection{Drying Equipment and Drying Procedure}

Drying experiments were performed in a cabinet laboratory type dryer installed in the Chemical Engineering Department of Yildiz Technical University, Istanbul, Turkey. The dryer basically consists of a centrifugal fan, an electric heater, an air filter and an electronic proportional controller. The air temperature was controlled by means of a proportional controller. Air velocity was kept at a constant value of $1.0 \mathrm{~m} / \mathrm{s}$ with an accuracy of $\pm 0.03 \mathrm{~m} / \mathrm{s}$ for all drying experiments, measured with a Testo 440 Vane Probe Anemometer, and flowed perpendicular to the bed. The samples were dried in the perforated square basket, which had a flow cross-section of $30 \mathrm{~cm}$ x $30 \mathrm{~cm}$. The air was circulated by a variable speed fan and heated by electricity. 
Experiments were performed at 40,50 and $60^{\circ} \mathrm{C}$. The fish sample, $50 \mathrm{~g}$, was uniformly spread in a square basket in a single layer after the desired drying conditions had stabilized. Weight loss of samples was measured by means of a load cell (REVERE SHBXM CC) and was recorded at 30 min intervals during drying. The drying process was stopped when the moisture content decreased to $18 \%$ (w.b.) from an initial value of $71.95 \%$ (w.b.).

\subsection{Mathematical Modeling of Drying Curves}

The moisture content of drying samples at time t can be transformed to moisture ratio $(M R)$ [12].

$\mathrm{MR}=\frac{\mathrm{M}_{\mathrm{t}}-\mathrm{M}_{\mathrm{e}}}{\mathrm{M}_{0}-\mathrm{M}_{\mathrm{e}}}$

where; $M_{t}$ is the mean moisture content of fish samples at a specific time ( $\mathrm{g}$ water/g dry matter), $M_{o}$ is the initial moisture content (g water/g dry matter), $M_{e}$ is the equilibrium moisture content (g water/g dry matter).

The analytical solution of Fick's second law is obtained as a slab geometry by assuming that the effective moisture diffusivity is constant and that shrinkage is neglible, external resistance is neglible, and that there is uniform of initial moisture distribution during the drying process [13]. Therefore, the effective moisture diffusivity coefficient was calculated by the following Equation 2:

$$
M R=\frac{M_{t}-M_{e}}{M_{0}-M_{e}}=\frac{8}{\pi^{2}} \sum_{n=0}^{\infty} \frac{1}{(2 n+1)^{2}} \exp \left(-\frac{(2 n+1)^{2} \cdot \pi^{2} \cdot D_{e f f}}{4 \cdot L^{2}} t\right)
$$

where, $D_{\text {eff }}$ is the effective moisture diffusivity $\left(\mathrm{m}^{2} / \mathrm{s}\right), L$ is half-thickness of the fish slab $(\mathrm{m}), n$ is the positive integer and $t$ is the drying time (s). Only the first term of Equation 2 is used for long drying times [14], hence Equation 3 is rearranged and the following expression can be obtained:

$$
M R=\frac{M_{t}}{M_{0}}=\frac{8}{\pi^{2}} \exp \left(-\frac{\pi^{2} \cdot D_{e f f}}{4 \cdot L^{2}} t\right)
$$
4:

The effective moisture diffusivity can be calculated from the slope $(K)$ of $\ln (M R)$ versus time $(t)$ plot according to Equation

$$
\begin{aligned}
& \ln (M R)=\ln \left(\frac{8}{\pi^{2}}\right)-\left(\frac{\pi^{2} \cdot D_{e f f}}{4 \cdot L^{2}} t\right) \\
& \mathrm{K}=\frac{\pi^{2} \mathrm{D}_{\text {eff }}}{4 \mathrm{~L}^{2}}
\end{aligned}
$$

In the present study, the drying curves were fitted to four different thin-layer drying models to select a suitable model for describing the drying process of fish fillet (Table 1).

Table 1. Mathematical models applied to the fish samples drying curves

\begin{tabular}{lll}
\hline Model name & Equation & References \\
\hline Henderson and Pabis & $M R=A_{o} \exp (-k . t)$ & {$[15]$} \\
Page & $M R=\exp \left(-k . t^{n}\right)$ & {$[16]$} \\
Logarithmic & $M R=a \exp (-k . t)+c$ & {$[1]$} \\
Midilli et al. & $M R=a \exp \left(\left(-k . t^{n}\right)+(b . t)\right)$ & {$[17]$} \\
\hline
\end{tabular}

$A_{o,} a, b, c, k, n$ : Constants in models, $M R$ : Moisture ratio, $t$ : Drying time 
In these equations, $M R$ represents the moisture ratio of the samples at any time and $\mathrm{t}$ is the drying time. The obtained data were fitted to the models and their corresponding constants were calculated using Statistica 6.0 program software (Statsoft Inc., Tulsa, OK). The coefficient of determination $\left(R^{2}\right)$ is one of the primary criteria for selecting the best model to define the drying curves. In addition to $R^{2}$, the reduced chi-square $\left(\chi^{2}\right)$ and root mean square error $(R M S E)$ values are used to determine the quality of the fit and they are calculated using Equations 6 and 7, respectively.

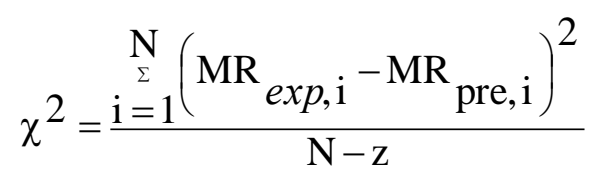

$R M S E=\left[\frac{1}{N} \sum_{i=1}^{N}\left(M R_{\text {pre }, i}-M R_{\text {exp }, i}\right)^{2}\right]^{1 / 2}$

where $M R_{\text {exp }, i}$ and $M R_{\text {pre }, i}$ are the experimental and predicted dimensionless $M R$, respectively, $N$ is the number of data values, and $z$ is the number of constants of the models. The best model describing the drying characteristics of samples was chosen as the one with the highest $R^{2}$, the least $\chi^{2}$ and RMSE [14].

\section{RESULTS AND DISCUSSION}

\subsection{Drying Curves}

\subsubsection{Influence of pre-treatment and temperatures on drying time}

The drying curves of moisture content versus drying time for pretreated and control samples are presented in Figure 1.
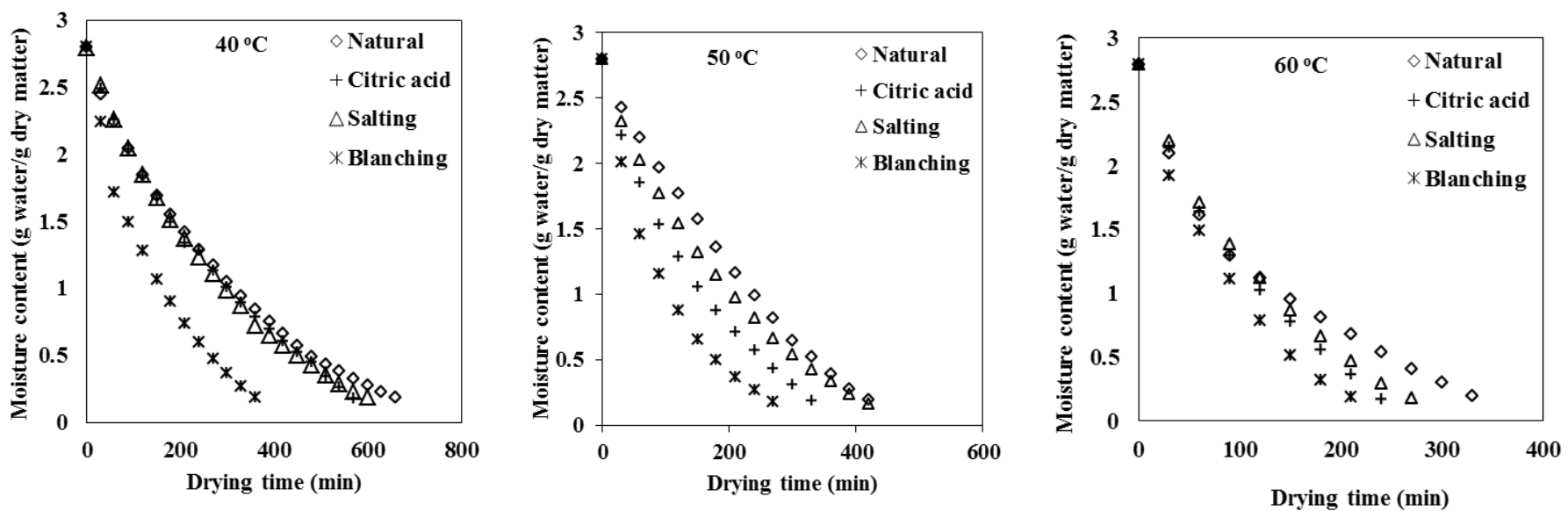

Figure 1. Variations of moisture content versus drying time for the control and various pretreated fish fillets at different temperatures

According to the results present in Figure 1, pre-treatment is very important parameter that affects the drying time. Also, the drying air temperature had a significant effect on the moisture content of the fish samples as expected. The results showed that drying time decreased greatly when drying temperature increased. Similar results were also reported for meat products by earlier researchers [18], [19]. The pretreated fish samples dried faster than the control samples, thus confirming the fact that pretreatment reduces the resistance to the movement of moisture, thereby increases the drying rate. Comparing the drying times of fish samples, it was concluded that blanched $>$ citric acid $>$ salted $\geq$ control. Drying time of blanched fish samples was found to have a shorter drying time by comparison with other pretreated (citric acid and salting) samples and the results show that blanching pre-treatment was more effective method in rainbow trout drying. The drying time required to reach final water content $18 \%$ 
(w.b.) for pretreated with blanching was $360 \mathrm{~min}$ at $40^{\circ} \mathrm{C}$. When the moisture ratio reduced to $20 \%$ an adequate drying was done. It is possible to decrease to this value till $15 \%$ to prevent mold growth [20], [21]. Corresponding values for citric acid, salted and control fish samples were 570, 600 and $660 \mathrm{~min}$, respectively. The difference in drying times of pretreated samples with blanching was shorter $36.85 \%, 40 \%$, and $45.46 \%$ than citric acid, salted and control fish samples, respectively. Similar trends were observed at drying temperatures of 50 and $60^{\circ} \mathrm{C}$. Başlar et al. reported that for the oven drying technique trout fillets dried at 1200,1050 and $930 \mathrm{~min}$ for the 55,65 and $75^{\circ} \mathrm{C}$, respectively. The results show that hot air drying worked in this study is the faster drying technique compared with oven drying in the mentioned study[22]. Besides, in this study pretreated samples had shorter drying times.

\subsection{Modeling of Drying Curves}

Thin-layer drying models have significant practical value to engineers for the preliminary evaluation of hot air drying operations. The moisture contents of samples were transformed into dimensionless moisture ratio to perform modeling studies easily. The values of the moisture ratio of fish samples were calculated using Equation 1. The experimental moisture ratios were fitted to four thin-layer drying models shown in Table 1. The statistical results from models are summarised in Tables 2-4.

Table 2. Curve fitting criteria for the various mathematical models and parameters of pretreated and control samples at

\begin{tabular}{|c|c|c|c|c|c|}
\hline \multicolumn{6}{|c|}{$40^{\circ} \mathrm{C}$} \\
\hline \multirow{2}{*}{ Models } & \multirow{2}{*}{ Parameters } & \multicolumn{4}{|c|}{ Pre-treatment } \\
\hline & & Blanching & Citric acid & Salting & Natural(control) \\
\hline \multirow[t]{3}{*}{ Henderson \& Pabis } & $R^{2}$ & 0.9949 & 0.9919 & 0.9919 & 0.9947 \\
\hline & $\chi^{2}$ & 0.000449 & 0.000650 & 0.000658 & 0.000419 \\
\hline & $R M S E$ & 0.019492 & 0.024187 & 0.023437 & 0.019547 \\
\hline \multirow[t]{3}{*}{ Page } & $R^{2}$ & 0.9953 & 0.9939 & 0.9971 & 0.9956 \\
\hline & $\chi^{2}$ & 0.000422 & 0.000492 & 0.000245 & 0.000347 \\
\hline & $R M S E$ & 0.018887 & 0.021048 & 0.014900 & 0.017788 \\
\hline \multirow[t]{3}{*}{ Logarithmic } & $R^{2}$ & 0.9951 & 0.9983 & 0.9996 & 0.9990 \\
\hline & $\chi^{2}$ & 0.000474 & 0.000145 & 0.000033 & 0.000081 \\
\hline & RMSE & 0.019090 & 0.011111 & 0.005294 & 0.008385 \\
\hline \multirow[t]{3}{*}{ Midilli et al. } & $R^{2}$ & 0.9986 & 0.9996 & 0.9997 & 0.9997 \\
\hline & $\chi^{2}$ & 0.000157 & 0.000044 & 0.000026 & 0.000037 \\
\hline & $R M S E$ & 0.010425 & 0.005941 & 0.004550 & 0.005518 \\
\hline
\end{tabular}

Table 3. Curve fitting criteria for the various mathematical models and parameters of pretreated and control samples at

\begin{tabular}{|c|c|c|c|c|c|}
\hline \multirow{3}{*}{ Models } & \multirow{3}{*}{ Parameters } & & & & \\
\hline & & \multicolumn{4}{|c|}{ Pre-treatment } \\
\hline & & Blanching & Citric acid & Salting & Natural(control) \\
\hline \multirow[t]{3}{*}{ Henderson \& Pabis } & $R^{2}$ & 0.9982 & 0.9962 & 0.9928 & 0.9799 \\
\hline & $\chi^{2}$ & 0.000181 & 0.000352 & 0.000649 & 0.001882 \\
\hline & RMSE & 0.012039 & 0.017119 & 0.023709 & 0.040363 \\
\hline \multirow[t]{3}{*}{ Page } & $R^{2}$ & 0.9991 & 0.9962 & 0.9946 & 0.9920 \\
\hline & $\chi^{2}$ & 0.000092 & 0.000353 & 0.000485 & 0.000749 \\
\hline & $R M S E$ & 0.008581 & 0.017142 & 0.020489 & 0.025460 \\
\hline \multirow[t]{3}{*}{ Logarithmic } & $\mathrm{R}^{2}$ & 0.9984 & 0.9980 & 0.9989 & 0.9991 \\
\hline & $\chi^{2}$ & 0.000189 & 0.000197 & 0.000113 & 0.000090 \\
\hline & RMSE & 0.011517 & 0.012166 & 0.009488 & 0.008465 \\
\hline \multirow[t]{3}{*}{ Midilli et al. } & $\mathrm{R}^{2}$ & 0.9997 & 0.9999 & 0.9997 & 0.9991 \\
\hline & $\chi^{2}$ & 0.000045 & 0.000007 & 0.000032 & 0.000099 \\
\hline & RMSE & 0.005169 & 0.002124 & 0.004822 & 0.008513 \\
\hline
\end{tabular}


O. Ismail, Ö. Gökçe Kocabay

Table 4. Curve fitting criteria for the various mathematical models and parameters of pretreated and control samples at $60^{\circ} \mathrm{C}$

\begin{tabular}{|c|c|c|c|c|c|}
\hline \multirow{2}{*}{ Models } & \multirow{2}{*}{ Parameters } & \multicolumn{4}{|c|}{ Pre-treatment } \\
\hline & & Blanching & Citric acid & Salting & Natural(control) \\
\hline \multirow[t]{3}{*}{ Henderson \& Pabis } & $R^{2}$ & 0.9946 & 0.9941 & 0.9944 & 0.9900 \\
\hline & $\chi^{2}$ & 0.000634 & 0.000639 & 0.000585 & 0.000856 \\
\hline & $R M S E$ & 0.021805 & 0.022277 & 0.021624 & 0.026703 \\
\hline \multirow[t]{3}{*}{ Page } & $R^{2}$ & 0.9948 & 0.9962 & 0.9957 & 0.9961 \\
\hline & $\chi^{2}$ & 0.000616 & 0.000530 & 0.000452 & 0.000422 \\
\hline & RMSE & 0.021494 & 0.020300 & 0.019013 & 0.018741 \\
\hline \multirow[t]{3}{*}{ Logarithmic } & $R^{2}$ & 0.9992 & 0.9980 & 0.9985 & 0.9910 \\
\hline & $\chi^{2}$ & 0.000069 & 0.000254 & 0.000173 & 0.000854 \\
\hline & RMSE & 0.006585 & 0.013001 & 0.010998 & 0.025310 \\
\hline \multirow[t]{3}{*}{ Midilli et al. } & $R^{2}$ & 0.9992 & 0.9997 & 0.9996 & 0.9980 \\
\hline & $\chi^{2}$ & 0.000145 & 0.000056 & 0.000045 & 0.000206 \\
\hline & RMSE & 0.008515 & 0.005553 & 0.005222 & 0.011726 \\
\hline
\end{tabular}

The best model describing the thin-layer drying characteristics of fish samples was chosen as the one with the highest $R^{2}$ values and the lowest $\chi^{2}$ and RMSE values. In all cases (from Tables 2-4), the statistical parameter estimations showed that $R^{2}$, $\chi^{2}$ and $R M S E$ values were ranged from 0.9865 to $0.9999,0.000007$ to 0.001051 , and 0.002124 to 0.031035 , respectively. As seen from the tables, the $R^{2}$ values were higher than 0.9865 , indicating a good fit since $R^{2}$ value close to unity implies that the predicted drying data were near the experimental drying data. This means that all established models successfully described the relation between time and $M R$. In other words; in fact, the $M R$ of the samples at any time of the drying process could be predicted using these models. Another statistical parameters calculated to compare the model's accuracy were the $\chi^{2}$ and $R M S E$ values, which represent the differences between the predicted and experimental values. Therefore, the fact that $\chi^{2}$ and $R M S E$ are close to zero is desired. As expected, the Midilli et al., model gives the highest values of $R^{2}$ and the lowest values of $\chi^{2}$ and $R M S E$ values for pretreated and control fish samples. The Midilli et al. model was also suggested by Darvishi et al. [12] to describe drying of sardine fish. On the other hand the logarithmic model was found to be the most suitable in describing the drying characteristics of rainbow trout fillets according to Ismail and Gokce Kocabay [23].

\subsection{Effective Moisture Diffusivity}

On the basis of Fick's second law, effective moisture diffusivity was calculated from Equation 5 and is shown in Table 5.

Table 5. Values of effective moisture diffusivity obtained from trout fillets dried at different temperatures and pretreatments

\begin{tabular}{ccc}
\hline Temperature $\left({ }^{\circ} \mathbf{C}\right)$ & Pre-treatment & Deff $^{\left(\mathbf{m}^{2} / \mathbf{s}\right)}$ \\
\hline & Blanching & $2.42 \times 10^{-9}$ \\
$\mathbf{4 0}$ & Citric acid & $1.42 \times 10^{-9}$ \\
& Salting & $1.38 \times 10^{-9}$ \\
& Natural (control) & $1.29 \times 10^{-9}$ \\
& Blanching & $3.34 \times 10^{-9}$ \\
& Citric acid & $2.48 \times 10^{-9}$ \\
& Salting & $2.03 \times 10^{-9}$ \\
& Natural (control) & $2.05 \times 10^{-9}$ \\
& Blanching & $3.91 \times 10^{-9}$ \\
& Citric acid & $3.71 \times 10^{-9}$ \\
& Salting & $3.03 \times 10^{-9}$ \\
& Natural (control) & $2.28 \times 10^{-9}$ \\
\hline
\end{tabular}


As seen in Table 5, the effective moisture diffusivity values were found to be between $1.29 \times 10^{-9}$ and $3.91 \times 10^{-9} \mathrm{~m}^{2} / \mathrm{s}$. As expected, effective moisture diffusivity values increased with pre-treatment and increase in drying temperature; it was also observed that the effective moisture diffusivity values were higher for blanching pre-treatment as compared to natural drying. Başlar et al. reported that the values of $D_{\text {eff }}$ remain within the general range of $10^{-12}$ to $10^{-8} \mathrm{~m}^{2} / \mathrm{s}$ for food materials [18].

\section{CONCLUSION}

When dried, the weight and volume of the rainbow trout is reduced, thus becoming smaller. This makes it easy to transportation and storage. The speed of other reactions, such as enzymatic, non-enzymatic, oxidation, decreases. Microbial degradation is also prevented. Thus, long shelf life is obtained as a result of drying.

In this study the effect of different pre-treatments and temperatures on drying of rainbow trout fish samples were investigated. The pre-treatment process decreased the drying time of fish fillets by comparison with control samples. Also, pretreated samples with blanching had shorter drying times (hence higher drying rates) by comparison with citric acid, salted and control fish samples. Drying data obtained were fitted to four thin-layer drying models and goodness of fit was determined using $R^{2}, \chi^{2}$, and $R M S E$ values. The Midilli et al. model gave the best representation of drying data under all experimental conditions. On the basis of Fick's second law, effective moisture diffusivity was calculated by Crank's equation. The effective moisture diffusivity values were significantly increased when blanching pre-treatment compared with natural drying. In view of the short drying time, the optimal drying temperature was found to be $60^{\circ} \mathrm{C}$. The results of this study proved that the experimental parameters and drying technique used in this study could be used to store rainbow trout of a certain size.

\section{REFERENCES}

[1] D. Jain, and P. B. Pathare, "Study the drying kinetics of open sun drying of fish," Journal of Food Engineering, vol. 78, no. 4, Feb., pp. 1315-1319, 2007.

[2] T. Baygar, N. Erkan, S. Metin, O. Ozden, and C. Varlik, "Determination of the shelf-life of stuffed rainbow trout during cold storage," Turkish Journal of Veterinary and Animal Sciences, vol. 26, no. 3, Feb., pp. 577-580, 2002.

[3] T. Mohd Rozainee, and P. S. Ng, "Microwave assisted hot air convective dehydration of fish slice: drying characteristics, energy aspects and colour assessment," World Engineering Congress 2010-Conference on Advanced Processes and Materials, 2010, pp. 41-46

[4] M. S. Brooks, N. H. Abou El-Hana, and A. E. Ghaly, "Effects of tomato geometries and air temperature on the drying behaviour of plum tomato," American Journal of Applied Science, vol. 5, no. 10, pp. 1369-1375, 2008.

[5] P. P. Lewicki, "Design of hot air drying for better foods," Trends in Food Science \& Technology, vol. 17, no. 4, Apr., pp. 153-163, 2006.

[6] K. Nagaya, Y. Li, Z. Jin, M. Fukumuro, Y. Ando, and A. Akaishi, "Low-temperature desiccant-based food drying system with airflow and temperature control," Journal of Food Engineering, vol. 75, no. 1, Jul., pp. 71-77, 2006.

[7] M. Y. Omodara, and A. M. Olaniyan, "Effects of pre-treatments and drying temperatures on drying rate and quality of African Catfish (Clarias gariepinus)," Journal of Biology, Agriculture and Healthcare, vol. 2, no. 4, ISSN 2224-3208 (Paper) ISSN 2225-093X (Online), 2012.

[8] T. S. Workneh, A. Zinash, and K. Woldetsadik, "Blanching, salting and sun drying of different pumpkin fruit slices," Journal of Food Science and Technology, vol. 51, no. 11, Nov., pp. 3114-3123, 2014.

[9] F. Haile, S. Admassu, and A. Fisseha, "Effects of pre-treatments and drying methods on chemical composition, microbial and sensory quality of orange-fleshed sweet potato flour and porridge," American Journal of Food Science and Technology, vol. 3, no. 3, Jan., pp. 82-88, 2015.

[10] E. E. Abano, L. K. Sam-Amoah, J. Owusu, and F. N. Engmann, "Effects of ascorbic acid, salt, lemon juice, and honey on drying kinetics and sensory characteristic of dried mango," Croatian Journal of Food Science and Technology, vol. 5, no. 1, Jan., pp. 1-10, 2013.

[11] AOAC, Official Methods of Analysis (15th ed.). USA: Association of Official Analytical Chemists, Arlington, VA, 1990.

[12] H. Darvishi, M. Azadbakht, A. Rezaeiasl, and A. Farhang, "Drying characteristics of sardine fish dried with microwave heating," Journal of the Saudi Society of Agricultural Sciences, vol. 12, no. 2, June., pp. 121-127, 2013.

[13] J. Crank, The Mathematics of Diffusion (Oxford Science Publications) (2nd revised ed.). United Kingdom: Clarendon Press, Oxford, 1979, pp- 414. 
O. Ismail, Ö. Gökçe Kocabay

[14] I. Doymaz, H. Demir, and A. Yildirim, "Drying of quince slices: effect of pretreatments on drying and rehydration characteristics," Chemical Engineering Communications, vol. 202, no. 10, May., pp. 1271-1279, 2015.

[15] S. M. Henderson, and S. Pabis, "Grain drying theory I. Temperature effect on drying coefficient," Journal of Agricultural Engineering Research, vol. 6, pp. 169-174, 1961.

[16] G. E. Page, "Factors influencing the maximum rates of air-drying shelled corn in thin layers," M. S. thesis, Purdue University, Purdue, USA, 1949.

[17] A. Midilli, H. Kucuk, and Z. Yapar, “A new model for single-layer drying,” Drying Technology, vol. 20, no. 7, Feb., pp. 1503-1513, 2002.

[18] M. Baslar, M. Kilicli, O. S. Toker, O. Sagdic, and M. Arici, "Ultrasonic vacuum drying technique as a novel process for shortening the drying period for beef and chicken meats," Innovative Food Science and Emerging Technologies, vol. 26, Dec., pp. 182-190, 2014.

[19] G. M. Kituu, D. Shitanda, C. L. Kanali, J. T. Mailutha, C. K. Njoroge, J. K. Wainaina, and V. K. Silayo, “Thin layer drying model for simulating the drying of Tilapia Fish (Oreochromis niloticus) in a solar tunnel dryer," Journal of Food Engineering, vol. 98, no. 3, June., pp. 325-331, 2010.

[20] S. Bellagha, E. Amami, A. Farhat, and N. Kechaou, "Drying kinetics and characteristic drying curve of lightly salted sardine (Sardinella aurita)," Drying Technology, vol. 20, no. 7, Feb., pp. 1527-1538, 2002.

[21] Z. H. Duan, M. Zhang, and J. Tang, "Thin layer hot-air drying of Bighead Carp.," Fisheries Science, vol. 23, no. 3, pp. 29-32, 2004.

[22] M. Baslar, M. Kilicli, and B. Yalinkilic, "Dehydration kinetics of salmon and trout fillets using ultrasonic vacuum drying as a novel technique," Ultrasonics Sonochemistry, vol. 27, Nov., pp. 495-502, 2015.

[23] O. Ismail, and O. Gokce Kocabay, "Infrared and microwave drying of rainbow trout: drying kinetics and modelling," Turkish Journal of Fisheries and Aquatic Sciences, vol. 18, no. 2, Jan., pp. 259-266, 2018. 